\title{
The impact of academic performance on self-esteem among the female students studying in different colleges under Royal University of Bhutan
}

\author{
Sonam Zangmo ${ }^{1}$, Ugyen Pem ${ }^{2}$, Kezang Choden ${ }^{3}$, Dorji Yangzom ${ }^{4}$ \\ ${ }^{1,4}$ Department of Counselling and Psychology Education, Samtse College of Education, Royal University of Bhutan, Bhutan \\ ${ }^{2,3}$ Department of Science Education, Samtse College of Education, Royal University of Bhutan, Bhutan
}

Received: 11 May 2021; Received in revised form: 16 Jun 2021; Accepted: 25 Jun 2021

(C2021 The Author(s). Published by TheShillonga. This is an open access article under the CC BY license (https://creativecommons.org/licenses/by/4.0/)

\begin{abstract}
The current study was carried out among the female students of The Royal University of Bhutan to evaluate the relationship between academic performance and self-esteem, and the factors affecting self-esteem. The study adopted concurrent triangulation design of mixed methodology to collect and analyse the data. A total of 491 female students participated in the survey and of which 34 of them participated in focus-group interview. The result of the quantitative analysis showed that there is a positive relationship between academic performance and self-esteem (rho=.170, $p<.05$ ), which attests to the similar earlier findings. Qualitative analysis explored Ackerman's nine factors influencing self-esteem. Of the nine factors influencing self-esteem, parental influence was shown to have the most effect on the participants' self-esteem. Based on the findings, the current study made a number of recommendations.
\end{abstract}

Keywords-Academic performance, Ackerman's nine factors influencing self-esteem, Self-esteem.

\section{INTRODUCTION}

Academic performance is the extent to which a student can learn and attain success in their studies. The successes of their studies are usually measured in terms of assessment scores. Academic performance of the students plays a crucial role in determining self-esteem. Nyadanu et al., (2014) stated that self-esteem has been used in psychology to reflect a person's overall emotional evaluation of his or her worth. It is a judgment of oneself as well as an attitude toward the self. Self-esteem includes the values and feelings of victory, despair, pride, and guilt (Hewitt, 2009 as cited in Nyadanu et al., 2014). Smith and Mackie (2007) defined self-esteem as the positive or negative views of the self, depending on how we perceive it (see Nyadanu et al, 2014). Therefore, self-esteem is described as a person's overall sense of self-worth and personal value.

According to Duari (2012), high self-esteem is when the person feels good, happy, satisfied about himself or herself and that thinks he or she is capable of achieving anything. Here, the person has lots of energy, focus, confidence and persistence to achieve success anytime. On the contrary, low self-esteem is when one doesn't feel good about oneself; one thinks that they are not worthy of even trying to move forward. Research studies have shown a close relationship between the academic achievements of students and their self-esteem.

A study by Ogot (2015) has found out that student's high self-esteem is significantly related to their academic performance. However, no such research has been conducted in Bhutan to depict the current status of the relationship between academic performance and selfesteem at a tertiary level. The purpose of this study was to investigate the relationship between academic performance and self-esteem by examining the factors influencing the self-esteem of female students studying in different colleges under Royal University of Bhutan. It will help the teachers, parents, and students to understand the effect of academic achievement on self-esteem and to realise the importance of associative relation between these variables. Besides, it would help educators to better understand their students by identifying the factors influencing the selfesteem of female students in the Bhutanese context. This study will create a provision for future researchers to find ways to motivate students to perform better in academics and to enhance the self-esteem of the students. 


\section{LITERATURE REVIEW}

Academic performance and self-esteem have a strong and positive association (Chohan, 2013) The study conducted by Moeller (1994) argues that academic performance seems more related to students' ability to set academic standards and persist in trying to meet them than it is to their self-esteem. The key to success in academic performances is to develop the motivation to set standards and to work hard for success. Moreover, Alpay (2004) argued that whilst academic success raises or maintains self-esteem, it is self-esteem which influences performance. Ahmad et al. (2013) further confirms that there is a favourable effect of high self-esteem on student's higher rate of interests in classroom activities, confident, positive attitudes towards classmates, sense of collaboration, motivation for learning and sharing of views in classroom discussions.

Several studies have found a significant and positive correlation between self-esteem and academic achievement (e.g., Aryana, 2010; Kharsah and Latada, 2016; Mirzaei-Alavijeh et al., 2018). However, according to Ahmad et al., (2018), there was a negative correlation between self-esteem and academic performance. Similarly, a study by Iniama (2004) found out that there is no significant relationship between academic performance and self-esteem. The findings are negative since the sampling was narrow and lacked specified focus. The focus of their studies were on both internal and external factors of personal perception of self-belief, furthering influencing the self-esteem level of an individual.

Self-esteem is considered a sort of measure of how much a person values, approves of, appreciates, prizes, or likes him or herself' (Adler and Stewart, 2004). According to self-esteem expert Rosenberg (1965), self-esteem is quite simply one's attitude toward oneself. He described it as a "favourable or unfavourable attitude toward the self".
Studies have found that students with high self-esteem perform better in schoolwork than students with low selfesteem (Rosli et al, 2011; Alokan et al., 2014). Ackerman (2018) in his study found that the following various factors have the potential to influence our self-esteem: Genetics, Personality, Life experiences, Age, Health, Thoughts, Social Circumstances, Reactions of others, and Comparing the self to others.

\section{RESEARCH METHODOLOGY}

\section{Research design}

This research is guided by the paradigm of pragmatism. According to Creswell, (2014) Pragmatists do not see the world as an absolute unity. This paradigm looks into many approaches for collecting and analysing data rather than subscribing to only one way. For the current study, data were gathered with the use of mixed methods. Mixed methods data collection approach refers to an emergent methodology of research that advances the systematic integration or blending of quantitative and qualitative data within a single inquiry (Wisdom and Creswell, 2013). A concurrent triangulation study was carried out to find the relationship between academic performance and self-esteem of female students of the Royal University of Bhutan. The study's concurrent triangulation design involved a single study containing qualitative and quantitative data collection which is conducted at the same time (Kroll and Neri, 2009).

Conceptual framework guides the paths of research and offer the foundation for establishing its credibility (Adom et al., 2018). Camp (2001) defined a conceptual framework as a structure which the researcher believes can best explain the natural progression of the phenomenon to be studied (Adom et al., 2018). The conceptual framework used in the current research is shown in figure 1.

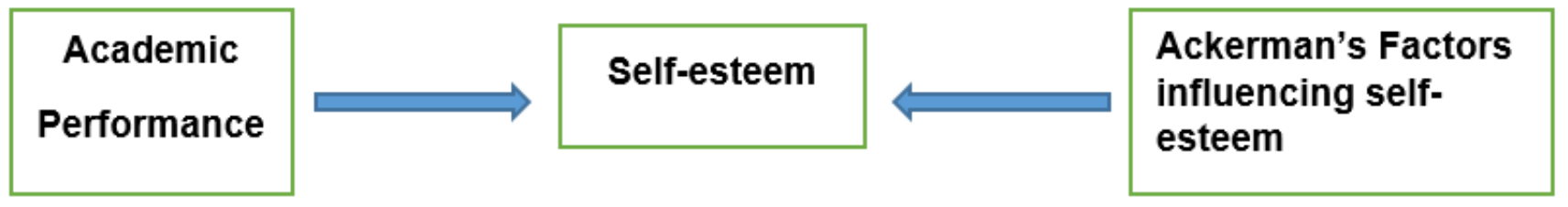

Fig.1: Conceptual Framework

\section{Sampling}

Stratified random sampling is a method of sampling that involves the division of a population into smaller sub-groups known as strata. It allows researchers to obtain a sample population that best represents the entire population being studied (Hayes and Westfall,
2020). 5248 female students are studying in different colleges under Royal University of Bhutan and for this study, 491 female students are randomly selected for survey questionnaire of which a total of 34 female students participated in focus-group interview.

Data Collection tools 
The quantitative data on measuring the self-esteem of female students are collected by using the Rosenberg Self-Esteem Scale. The scale has ten items with Four Point Likert Scale ranging from strongly agree to strongly disagree (Rosenberg, 1965). The academic performance of previous semester of the female students is included in the adapted version of Morris Rosenberg's Self-Esteem Scale with Four Point Likert Scale ranging from outstanding to fail (The Wheel of Academic Law, 2017).

The qualitative data on investigating the factors influencing the self-esteem of female students were collected through a semi-structured interview. Open-ended questions were asked in the semi-structured interview based on the following nine factors like Parental influence, Personality, Life experiences, Age, Health, Thoughts, Social circumstances, Reactions of others, and Comparing self to others.

\section{Findings}

The current study used an alpha level of 0.05 for all statistical analyses. Table 1 shows the distribution of participants' score on self-esteem scale and academic performance rank.
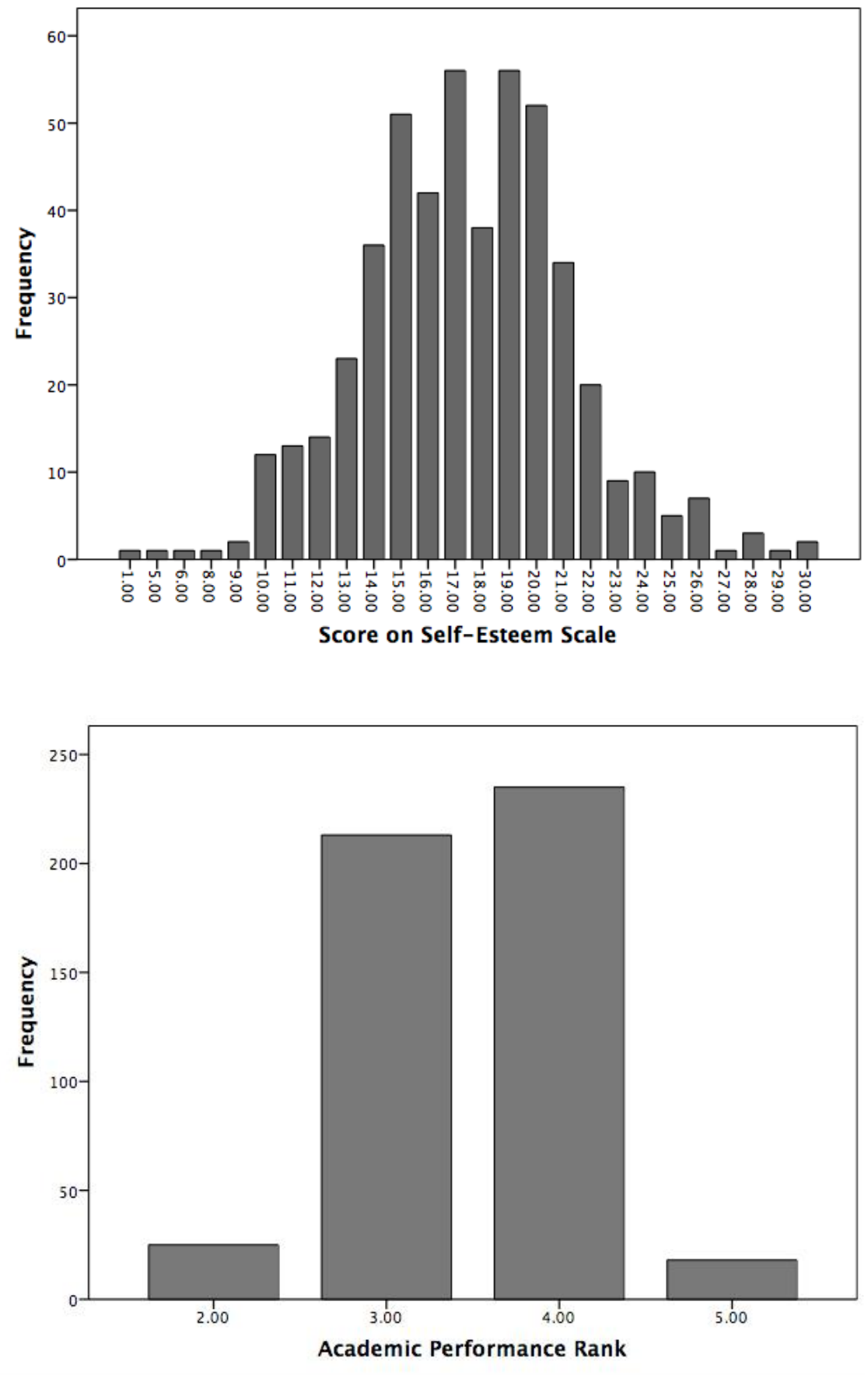
A Spearman's rank-order correlation test was conducted to assess the relation between students' academic performance and their self-esteem. Academic performance and self-esteem were positively correlated at $r h o=.170, p<.05$.

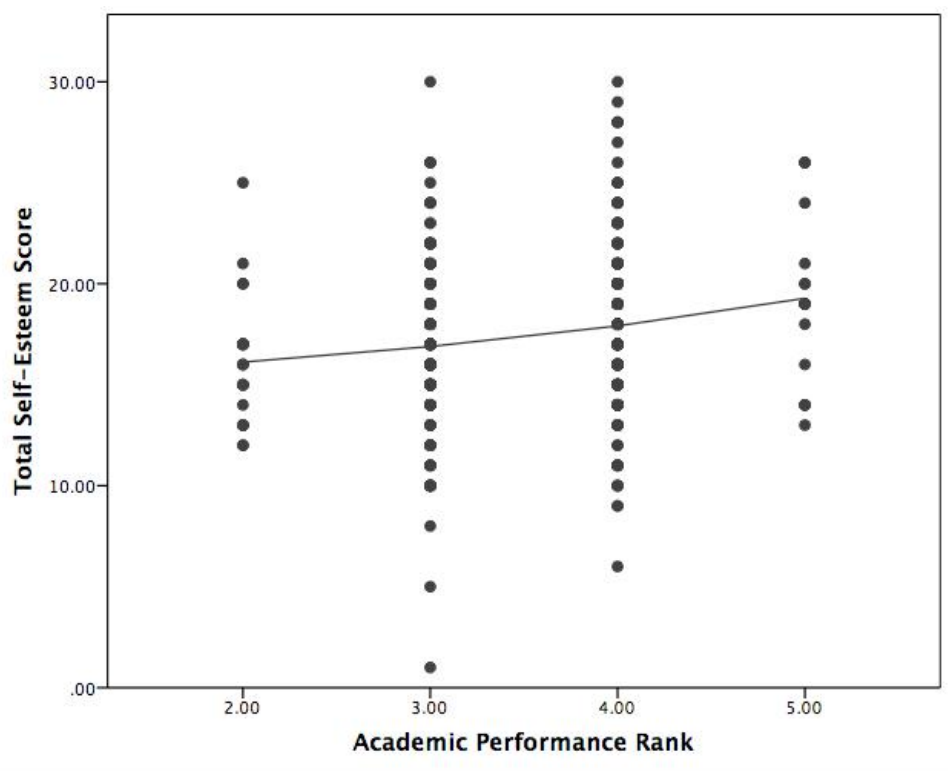

Nine factors influence self-esteem (Ackerman, 2018) and they are;

1. Parental influence

Parental influence includes the self-esteem of participants' parents and issues related to self-esteem faced by their family. From the quantitative data analysis, approximately $84 \%(n=412)$ of the participants agreed that they are satisfied with themselves. Majority of the participants' parents have high self-esteem. A few participants were found to have low self-esteem because their siblings did not perform well in academics. FGI 7 , $12,15,17,19$ and 20 said that their siblings had low selfesteem due to academic issues. Parental influence has an impact on the self-esteem of the participants. Self-esteem was influenced by the support received from their parents.

\section{Personality}

Personality comprises characteristics, feelings, and attitude of the participants. Around $82 \%(n=403)$ of the participants agreed that they feel that they have several good qualities. From the focus group interviews, around $47 \%(n=16)$ of the participants were found to be introvert. Most of the participants have shared that they lack selfconfidence because of their poor academic performance thus feeling useless. The participant FGI 9 said, 'I have difficulty in expressing my thoughts and feelings in words.' The feelings of possessing good qualities and academic performance influence self-esteem.

\section{Life Experiences}

Life experiences involve daily life experiences and ability to overcome daily life challenges. From a focus group interview, around $41 \%(n=14)$ of the participants are affected by daily events. From quantitative data, 62\% $(n=305)$ of the participants agreed that they feel useless at times. Out of two coping mechanisms, 44\% $(n=15)$ have used self-help. On the other hand, $44 \%(n=15)$ resorted to external sources of support to overcome their life challenges. According to FGI 30, 'I overcome the challenges in life by thinking about the remedy to solve the problem. If I can't find a way then I ask my friends and if it's serious I discuss it with my parents.' According to FGI 21, 'I overcome challenges in my life with positive thoughts. And my parents provide emotional support to boost my confidence.' Daily events and the ability to cope with life challenges also influence self-esteem.

\section{Age}

Age focuses on the relationship between chronological age and the development of self-esteem. About $82 \%(n=28)$ of the focus group participants have said that there was a positive change in their self-esteem over the years. Most of the participants said that their selfesteem was low during childhood since they were dependent on their parents, relatives and caregivers. The participant FGI 25 said, 'When I was young, I was an introvert. I couldn't talk to my friends and teachers. But as I grew up I can face crowds because of my schooling and experiences.' Age has a positive impact on self-esteem.

5. Health 
Health indicates the absence of any disease or impairment and its influence on their self-esteem. Around $79 \%(n=27)$ of the participants have said that good health leads to high self-esteem and poor health leads to low selfesteem. Majority of the participants during the focus group interview expressed that having good health enables them to perform well in studies since they were able to take part in all the events conducted in the college. Good health contributes to high self-esteem.

\section{Thoughts}

Thoughts include thinking, other's views, and attitude. Approximately $74 \%(n=25)$ of participants from the focus-group interview had positive thoughts and $85 \%$ $(n=29)$ of the participants felt that others' views on them were positive. Around 95\% $(n=467)$ of the participants from quantitative data agreed that they take a positive attitude toward themselves. Positive thoughts and attitude lead to high self-esteem.

\section{Social Circumstances}

Social circumstances emphasize in making friends and social preference. Approximately 59\% $(n=20)$ of the participants were able to make friends easily. However, when participants were asked about their social preferences about $65 \%$ (22) of the participants' social preference was found to stay at home. Social circumstances and social preferences cannot determine self-esteem.

\section{Reactions of others}

Reactions of others focus on giving importance to others and seeking other approvals. About $85 \%(n=29)$ of the participants were found to give importance to other views and were bothered by disagreement. FGI 8 said, 'I need others' approval. I try to convince others to agree with me.' Reactions of others can influence self-esteem.

\section{Comparing self to others}

Comparing self to others focus on the frequency and area of comparison, approximately $82 \%(n=28)$ of the participants from qualitative data were found not comparing themselves with others. The participant FGI 32 said, 'I don't compare my life with others. I feel comparing makes us weak and leads to negative thoughts often.' The area of the comparison made by the remaining participants was academic and personality. Comparing self to others does not influence self-esteem.

\section{DISCUSSION}

Out of nine identified factors by Ackerman (2018) that influenced the self-esteem of participants in this study are parental influence, age, thoughts, reactions of others, and comparing self to others. Majority of the participants were found to have high self-esteem because of the support received from their parents. In contrast, some of the participants of focus group interview were found to have low self-esteem due to family issues like financial crisis, broken family, unplanned pregnancy, drug abuse and comparison with others. So far no studies have been carried out to find out the parental influence on selfesteem. Many psychologists found that young adulthood is the stage in which people tend to take more and more complex social roles and responsibilities. The participants' self-esteem has drastically increased in their adulthood as they become independent and take more responsibilities. Seligman defined "Positive thinking does not necessarily mean avoiding or ignoring the bad things; instead, it involves making the most of the potentially bad situations, trying to see the best in other people, and viewing yourself and your abilities in a positive light." (Cherry, 2019). In contrast, negative thoughts are cognitions about the self, others, or the world in general that are characterised by negative perceptions, expectations, and attributions and are associated with unpleasant emotions and adverse behavioral, physiological, and health outcomes (Hawkley, 2013). The findings suggested that the participants had positive thoughts. In contrast, the majority of the participants expressed that they are worried about their future. Nyuyen et al. (2019) found out there was an association among lower self-esteem and increased anxiety.

According to Cikanavicius (2018), many people learn that their fundamental sense of self-esteem and selfworth comes not from within but from others, and so they seek other people's approval or attention. Majority of the participants were found to be bothered by other's opinions and disagreements. Comparing self with others can have a negative impact on self-esteem. It can change the perception of life as a whole. Majority of the participants do not compare themselves with others. Psychologist Carl Rogers (1959) stated that a person who has high selfesteem has a high level of confidence and positive feelings about himself or herself, faces challenges in life, accepts failure and unhappiness at times, and is open with people. Self-esteem and academic performance of the participants are positively correlated. A study by Baumeister et al. (2003) found out that high self-esteem does not lead to good performance. A study conducted by Ahmad et al. (2018) found that there was a negative correlation between self-esteem and academic performance. On the contrary, similar studies have been carried out and found out that students with a high level of self-esteem have a high level of academic achievements (Alpay, 2004; Chohan, 2013; Arshad et al., 2015; Ogot, 2015). 


\section{CONCLUSION}

A concurrent triangulation study is carried out to find out the influence of nine factors identified by Ackerman (2018) and draw a correlation between selfesteem based on Morris Rosenberg's scale and academic performance of the female students of Royal University of Bhutan. It is found out that five factors out of nine influence the self-esteem of female students. The remaining four factors that influence self-esteem are not taken into account because of the statistical analysis of each factor (less than $80 \%$ ). The correlation between selfesteem and academic performance is found to be weakly (positive) correlated. The result of the correlation does not support the conceptual framework which states high academic performance leads to high self-esteem and viceversa. However, considering the limitations of the current study, it is suggested that in future male students to be included in the sample and focus on one factor that influences self-esteem. To get a more accurate correlation of academic performance and self-esteem, the future researchers can study on low academic performance and self-esteem of the students.

\section{RECOMMENDATIONS}

Future researchers could select specific factor that influences the self-esteem, focus on the students from the same academic performance level, and mixed gender.

\section{REFERENCES}

[1] Ackerman, E.C., (2021, January 18). What is Self-Esteem? A Psychologist Explains PositivePsychology.com. https://positivepsychology.com/self-esteem/

[2] Adom, D., \& Hussein, E.K. (2018). Theoretical and Conceptual Framework: Mandatory Ingredients of a Quality Research. International Journal of Scientific Research $7(1): 438-441$ `https://www.researchgate.net/publication/322204158_THE ORETICAL_AND_CONCEPTUAL_FRAMEWORK_MA NDATORY_INGREDIENTS_OF_A_QUALITY_R ESEARCH

[3] Admad, I., Zeb, A., Ullah, S., Ali, A. (2013). Relationship between Self-Esteem and Academic Achievements of Students: A Case of Government Secondary Schools in District Swabi, KPK, Pakistan. International J. Soc. Sci. \& Education. 3(2), 361-369. https://www.researchgate.net/publication/271046753_S $\underline{\text { elf- }}$

Esteem_and_Academic_Performance_of_freshmen_at_ Karunya_University

[4] Ahmat, S. N., Muda, M. R., \& Neoh, C. F. (2018). SelfEsteem Level and Its Relationship to Academic Performance among Undergraduate Pharmacy Students in a Malaysian Public University. Indian Journal of
Pharmaceutical Education and Research, 52(2), 5. doi:10.5530/ijper.52.2.21

[5] Amirazodi, F., \& Amirazodi, M. (2011). Personality traits and Self-esteem. Procedia-Social and Behavioral Sciences, 29, 713-716. https://doi.org/10.1016/j.sbspro.2011.11.296

[6] Arshad, M. (2015). Self-Esteem \& Academic Performance among University Students. Journal of Education and Practice, 7. https://files.eric.ed.gov/fulltext/EJ1083788.pdf

[7] Arslan, C., \& Y1lmaz, A. (2015). Analyzing Decision Making Styles and Self-esteem at Decision Making of University Students Regarding to Shyness and Self-esteem Level. British Journal of Education, Society \& Behavioural Science, $\quad 8(4), \quad 227-234$. https://doi.org/10.9734/BJESBS/2015/16123

[8] Aryana, M. (2010). Relationship Between Self-esteem and Academic Achievement Amongst Pre-University Students. Journal of Applied Sciences, 10: 2474-2477. https://scialert.net/fulltext/?doi=jas.2010.2474.2477

[9] Alokan, F.B., Ogunsanmi, J.O., Makinde, V.I., \& Fashina, B.O. (2014). Influence of Self- esteem on Academic Performance Among Secondary School Students. IOSR Journal of Research \& Method in Education (IOSRJRME), 4(5), $\quad$ PP 48-51. http://www.iosrjournals.org/iosr-jrme/papers/Vol4\%20Issue-5/Version- 6/H04564851.pdf

[10] Chohan, B.I. (2013). An Exploratory Study of the Relationship between Self-Esteem and Academic Performance of the Students. Fatima Jinnah Women University, Rawalpindi. Journal of Educational Research $16 \quad$ (1), 39-50. https://www.researchgate.net/publication/259038804_An_ Exploratory_Study_of_the_Relationship_between_SelfEsteem_and_Academic_Performance_of_the_Students/link /0deec529cad4a9d5f8000000/download

[11] Creswell, J. W. (2014). Research design: Qualitative, quantitative, and mixed methods approach ( $4^{\text {th }}$ ed.). USA, SAGE.

[12] Department of Social work, Research Scholar, Bishop Heber College (Autonomous), Bharathidasan University, Trichirappalli, TamilNadu, Priyadharshini. J, J., \& A, Dr. R. (2014). Self-Esteem and Academic Performance of freshmen at Karunya University. IOSR Journal of Humanities and Social Science, 19(4), 21-26. https://doi.org/10.9790/0837-19432126

[13] Duari, P. (2012). Importance of self-esteem among students in academic performance and coping with stress. Indian Journal of Positive Psychology.3(4),1.https://www.questia.com/library/journal/ 1P3-3465849051/importance-of-self-esteemamong-students-in-academic

[14] D’Mello, L., Monteiro, M., \& Pinto, N. (2017). A Study On The Self Esteem And Academic Performance Among The Students. International Journal of Health Sciences and $\begin{array}{lll}\text { Pharmacy } & \text { (IJHSP), } & \text { 2(1), }\end{array}$ https://srinivaspublication.com/wpcontent/uploads/2018/12/1.-Self-Esteem_-FullPaper.pdf 
[15] Iniama, E. (2004). The relationship between self-esteem and academic performance of freshman at the University of the Virgin Islands, Annual conference of the Caribbean Studies Association, Marriott Hotel, St. Kitts, June 2004.

[16] Khan, B. (n.d.). Relationship between Self-Esteem and Academic Achievements of Students: A Case of Government Secondary Schools in District Swabi, KPK, Pakistan International J. Soc. Sci. \& Education. 3(2). http://ijsse.com/sites/default/files/issues/2012/volume\%203 \%20issue\%202,\%202012/paper/Paper-10.pdf

[17] Kroll, T., \& Neri, M. (2009). Designs for Mixed Methods Research. In S. Andrew \& E. J. Halcomb (Eds.), Mixed Methods Research for Nursing and the Health Sciences (pp. 31-49). Wiley-Blackwell. https://doi.org/10.1002/9781444316490.ch3

[18] Kharsah, W.S., \& Latada, F. (2016). The Correlation between Levels of Self-Esteem, University Commitment and Academic Performance among Undergraduate Students. The National Conference for Postgraduate Research 2016, Universiti Malaysia Pahang.

[19] Mixed Methods: Integrating Quantitative and Qualitative Data Collection and Analysis While Studying PatientCentered Medical Home Models. (n.d.).

[20] Mirzaei Alavijeh, M., \& Rahimi, H., \& Karami Matin, B., \& Jalilian, F. (2018). Self-Esteem and Academic Achievement Among Students of Kermanshah University of Medical Sciences (Brief Report). Educational Research In Medical Sciences, 7(1), 0-0. https://www.sid.ir/en/journal/ViewPaper.aspx?id=702868

[21] Moeller, T. G. (1994). What research says about selfesteem and academic performance. Education Digest, 59(5), 34.

http://search.ebscohost.com/login.aspx ?direct=true \&db $=\mathrm{a} 9 \mathrm{~h} \& \mathrm{AN}=9312297562 \&$ sit=ehost-live

[22] Nezlek, J. B., \& Plesko, R. M. (2001). Day-to-Day Relationships among Self-Concept Clarity, Self-Esteem, Daily Events, and Mood. Personality and Social Psychology Bulletin, 27(2), 201-211. https://doi.org/10.1177/0146167201272006

[23] Nyadanu, S. D., Garglo, M. Y., Adampah, T., \& Garglo, R. L. (2014). The Impact of Lecturer-Student Relationship on Self-Esteem and Academic Performance at Higher

Education. Journal of Social Science Studies, 2(1), 264. https://doi.org/10.5296/jsss.v2i1.6772

[24] Ogot, A. W. (2015). Relationship Between Self Esteem and Academic Performance of Students in Selected High Schools in Njoro District, Nakuru County, Kenya. International Journal of Science and Research (IJSR). 6(3), 2234-2237 https://www.ijsr.net/archive/v6i3/ART20171752.pdf

[25] Rosenberg, M. (1965). Rosenberg Self-Esteem Scale. https://fetzer.org/sites/default/files/images/stories/pdf/selfm easures/Self_Measures_for_SelfEsteem_ROSENBERG_SELF-ESTEEM.pdf

[26] Rosli, Y., Othman, H., Ishak, I., Lubis, S. H., Saat, N. Z. M., \& Omar, B. (2012). Self-esteem and academic performance relationship amongst the second-year undergraduate - students of Universiti Kebangsaan
Malaysia, Kuala Lumpur Campus. Procedia-Social and Behavioral Sciences, 60, 582-589. doi: 10.1016/j.sbspro.2012.09.426 